УДК 338.1.631

JEL classification: D24, P27, P32, Q12, Q13, Q17, Q18

Лупенко Ю. О.

доктор економ. наук, професор, ORCID: 0000-0001-6846-0300 академік Начіональної академії аграрних наук, Національний науковий центр «Інститут аграрної економіки»

Андрос C. B. доктор економ. наук, доиент, пров. наук. співробітник ORCID: 0000-0001-5561-901X

Національний науковий центр «Інститут аграрної економіки»

\title{
ПОГЛЯД НА АГРОПРОМИСЛОВИЙ КОМПЛЕКС УКРАЇНИ КРІЗЬ ПРИЗМУ АНАЛІЗУ СТАТИСТИЧНИХ ДАНИХ
}

\section{LOOK AT THE AGRICULTURAL COMPLEX OF UKRAINE THROUGH THE PRISM OF ANALYSIS OF STATISTICAL DATA}

Визначені характерні особливості українського сільськогосподарського ринку. Піднімаються актуальні проблеми, пов'язані з економічними заходами в сфері АПК, щзо викликають відносно невеликі перекоси в ијнах на ресурси, придбані сільгосппідприємствами, і продукцію, вироблену сільським господарством, про що свідчать помірні значення індикаторів захисту, усереднені по суб'єктах держави. Проведено аналіз ринку сільського господарства України. Проаналізовано ключові індикатори сільськогосподарського виробництва та торгівлі. Розглянута структура сільськогосподарських угідь та структура земельного фонду України. Обтрунтовано, щุо великі аграрні холдинги більш продуктивні, ніж фермерські господарства. Представлена структура фермерських господарств. Показана частка посівної площі та частка посівної площі сільськогосподарських культур у загальній посівній площі зернових та зернобобових культур. Розглянута загальна структура посівів сільськогосподарських культур. Проаналізовані тенденції виробництва сільськогосподарських культур. Встановлені проблели низької продуктивності фермерських господарств. Сформульовані ключові причини низької рентабельності виробництва продукції тваринництва. Представлено рівень рентабельності виробництва продукції рослинництва. Доведено, щзо основним напрямком украӥнського аграрного бізнесу є продукція рослинництва. Доведено, щэо аграрна сфера $\epsilon$ однією з вирішальних за часткою у ВВП Украйни. Встановлено, що до найбільш експортно-орієнтованих галузей української економіки відносяться сільське господарство $і$ харчова промисловість. Доведено, щуо основний експортний дохід Україна отримує від продажу соняшникової олії, пшеничі і кукурудзи. Доказано, шчо ефективність українського аграрного бізнесу набагато нижче, ніж у країнах $С С$. Показано співвідношення виробництва $i$ доходів від експорту української сільськогосподарської продукиї. Визначено ичільові напрями реалізачії існуючих програм розвитку аграріїв. Сформульовані основні тренди ринку сільського господарства та визначено позитивні і негативні фактори впливу на його розвиток. Запропоновано конщептуальний підхід щодо розвитку агропромислового комплексу України. Розроблено рекомендаиії щзодо вирішення існуючих проблем у секторі 
сільського господарства. Запропоновано перелік оптимальних умов для ефективної діяльності фермерських господарств $i$ розвитку приватного ринку за рахунок часткового перегляду заходів підтримки сільського господарства в Україні.

Ключові слова: агропромисловий комплекс, сільгоспвиробництво.

The characteristic features of the Ukrainian agricultural market are determined. Actual problems are being raised related to economic measures in the agricultural sector, causing relatively small distortions in the prices of resources acquired by agricultural enterprises and products produced by agriculture, as evidenced by the moderate values of protection indicators averaged by state entities. The agricultural market of Ukraine is analyzed. The key indicators of agricultural production and trade are analyzed. The structure of agricultural land and the structure of the land fund of Ukraine are considered. It is proved that large agricultural holdings are more productive than farms. The structure of farms is presented. The structure of the sown area and the structure of the sown area of agricultural crops in the total sown area of grain and leguminous crops are shown. The general structure of crops of crops is considered. The trends in crop production are analyzed. The problems of low productivity of farms are identified. The key reasons for the low profitability of livestock production are formulated. The level of profitability of crop production is presented. It is proved that the main direction of the Ukrainian agricultural business is crop production. It is proved that the agricultural sector is one of the decisive in terms of the share of Ukraine's GDP. It has been established that the most export-oriented sectors of the Ukrainian economy include agriculture and the food industry. It is proved that the main export income Ukraine receives from the sale of sunflower oil, wheat and corn. It is proved that the efficiency of the Ukrainian agricultural business is much lower than in the EU countries. The ratio of production and export earnings of Ukrainian agricultural products is shown. Targeted areas for the implementation of existing programs for the development of farmers are identified. The main trends of the agricultural market are formulated and the positive and negative factors of influence on its development are determined. A conceptual approach to the development of the agricultural sector of Ukraine is proposed. Recommendations have been developed to address existing problems in the agricultural sector. A list of optimal conditions for the effective operation of farms and the development of the private market through a partial review of agricultural support measures in Ukraine are proposed.

Keywords: agro-industrial complex, agricultural production.

Вступ. При належній соціально-економічній політиці і в певних інституційних умовах підприємства агропромислового комплексу України можуть успішно функціонувати і забезпечувати вагомий вклад у розвиток економіки. Великі розміри займаних площ, кліматичні умови, людський капітал і родючість грунтів обумовлює високий потенціал результативності сільгоспвиробництва. Завдяки таким перспективам АПК може стати надійним підгрунтям економічного зростання і зниження рівня бідності для більшої частини населення України.

Незважаючи на існуючі нині позитивні тренди в розвитку українських сільгосппідприємств, розрив між можливою і фактичною продуктивністю великий. Для того, щоб розробити необхідні економічні заходи, спрямовані на зменшення цього розриву, важливо провести чітку межу між обсягами виробництва і результативністю виробництва або продуктивністю (рентабельністю). 
В епоху СРСР великі обсяги виробництва сільськогосподарської продукції були обумовлені величезними субсидіями, а не ефективністю. Сьогодні така орієнтація на обсяги виробництва і самозабезпеченість за всяку ціну (почасти такий підхід працює) є недоречною. Якщо прийняти до уваги, що сільгосппідприємства отримували великі субсидії і що виробництво було неприйнятне в якості кінцевої мети економічних заходів, то певне зменшення обсягів сільгоспвиробництва України в перехідний період було зрозумілим і навіть бажаним. Занепокоєння викликає той факт, що після адаптації до нових цінових умов, рентабельність виробництва сільгосппродукції в кращому випадку залишається критично низькою. Дійсно, реформи в АПК повинні допомогти українським сільгоспвиробникам усвідомити свій величезний продуктивний потенціал.

Широке коло питань аграрної політики розглянули в своїх роботах $\mathrm{S}$. Bojnec i L. Latruffe [1]. Свій здобуток у методологію аналізу АПК країн 3 використанням економіко-математичних методів внесли А. Capkovicova i T. Hlavsa [2]. Продуктивність і ефективність фермерських господарств в країнах світу досліджували M. Gorton i S. Davidova [3]. Аналізом технічної й економічної ефективності сімейних фермерських господарств Італії з використанням набору даних займався N. Galuzzo [4]. Економічна життєздатність фермерських господарств на прикладі нових країн $Є \mathrm{C}$ розглянута V. Jodkiene, J. Savickiene [5]. Продуктивність і ефективність фермерських господарств у перехідний період досліджували Z. Lerman, W.R. Sutton та інші [6-11]. Разом з тим, комплексний підхід до формування системи АПК є не до кінця розробленим, не обгрунтована структура загального стану АПК, включаючи економіко-статистичний аналіз взаємозв'язку між окремими його сферами.

Постановка завдання. Мета статті полягає в науковому обгрунтуванні методичних підходів до нормалізації організаційноекономічних умов діяльності сільгоспвиробників на засадах комплексного економіко-статистичного аналізу індикаторів АПК.

Методологія. Методологічною основою статті $є$ праці зарубіжних вчених, дані Державної служби статистики і Світового банку, а також статистичні методи: зведення, угруповання; графічний метод; абсолютні, відносні і середні величини; індексний і кореляційно-регресійний аналіз. Обробка статистичних даних проводилася за допомогою універсального пакета прикладних програм Microsoft Excel.

Результати дослідження. Сільське господарство України має значний потенціал, завдяки сприятливим аграрним і кліматичним умовам. Більше половини території країни, 54\%, або приблизно 32 мільйонів гектарів - орні землі, з яких більше половини - родючі чорноземи в світі. Володіючи приблизно однієї третиною світових запасів чорноземів, Україна має в своєму розпорядженні потужну базу для вирощування 
сільськогосподарських культур, тваринництва та виробництва біомаси для використання в енергетиці.

Сільське господарство і харчова промисловість України відіграють важливу роль на національній і міжнародній арені; тут зайнято $23 \%$ населення і використовується $71 \%$ величезних земельних площ $-42,8$ млн га (рис. 1-2). По-суті, 27,5 мільйонів гектарів використовується нині для вирощування сільськогосподарських культур.

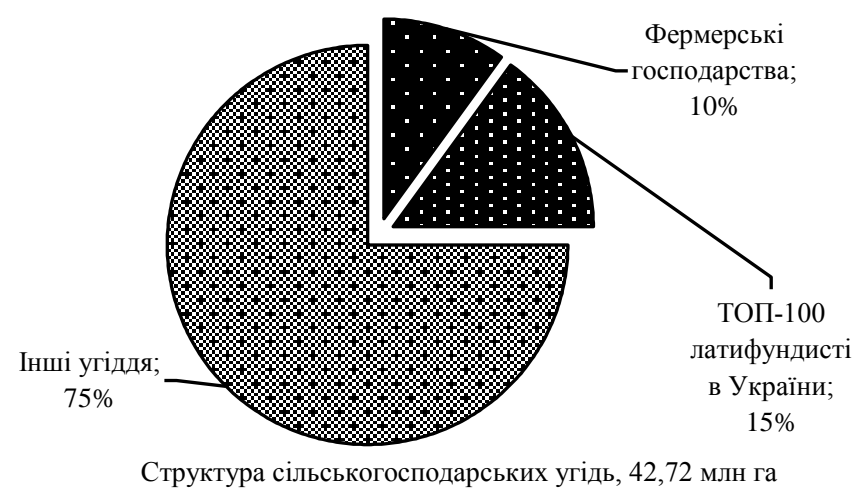

Рисунок 1 - Структура сільськогосподарських угідь, 2016 р., \% Джерело: складено за [12].

В Україні до тепер триває важливий процес консолідації земель, зростає кількість корпоративних фермерських господарств, які переходять під контроль великих агрохолдингів, які обробляють 13\% основних земель сільськогосподарського призначення.

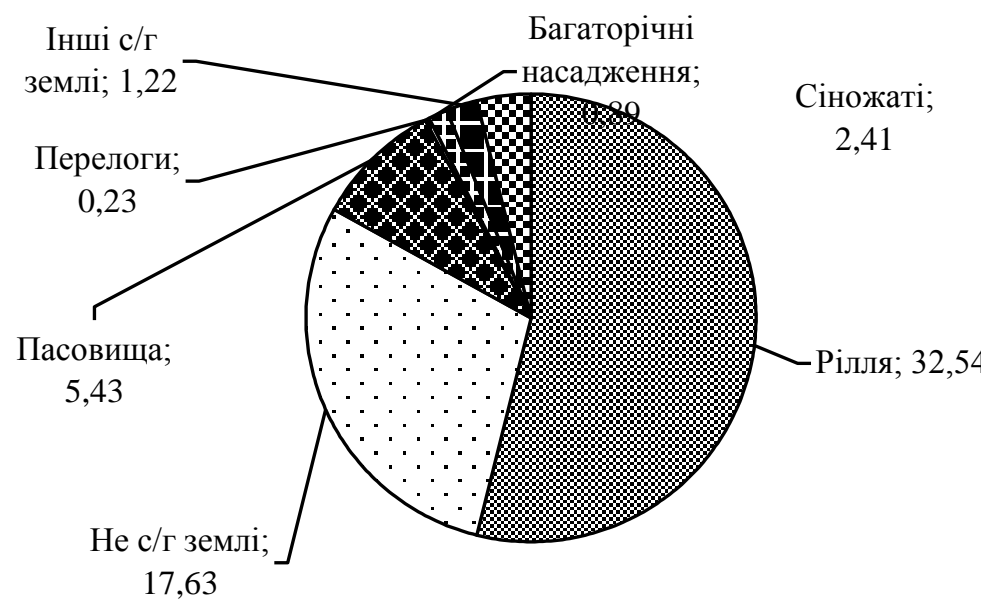

Рисунок 2 - Структура земельного фонду України, 2016 р., млн грн Дюкерело: складено за [12].

На сьогодні десяти найбільшим агрохолдингам належить близько 15\% всіх орних земель України. Середня врожайність на полях будь-якого 3 холдингів, в середньому, в два рази вище, ніж у дрібних підприємців. У той же час середні і дрібні фермерські господарства дають роботу 
більшості зайнятих у сільському господарстві сільських жителів. Цей тренд свідчить не тільки про ефективність агрохолдингів, а й демонструє серйозний виклик для соціальної політики держави в сфері АПК, бо підвищення ефективності і подальше зростання агрохолдингів означає збільшення безробіття в селах і погіршення соціальної ситуації.

Tак, Ukrlandfarming 3 кожним роком зростає: постійне збільшення земельного банку, поглинання інших агрофірм, нарощування доходу, збільшення кількості фахівців. Хоча в неї найбільший земельний банк, ефективність іï роботи не найвища. Тому що найбільша EBITDA на гектар у компанії «Астарта-Київ»: 370 доларів проти 324. Річ у тім, що більша кількість землі вже не гарантує більшого доходу. Тепер потрібно інвестувати в технології, які підвищують урожайність, збільшують ефективність інших напрямків діяльності і зменшують витрати. Холдинг має досить диференційований перелік напрямків - від рослинництва i тваринництва до виробництва цукру та надання техобслуговування [13].

У той же час, сектор селянських господарств переживає різке падіння. Нині на ринку України працює понад 40 тис сільськогосподарських підприємств (рис. 3). Для порівняння: в кінці 1955 року на території Української РСР було близько 15400 колгоспів.

На кінець 2016 року кількість діючих фермерських господарств склала 33682 одиниць, площа с/г угідь в їх користуванні - 4437,9 тис га, або 22,3\% від загального землекористування с/г підприємствами. В середньому на одне фермерське господарство припадає 131,7 га сільськогосподарських угідь.

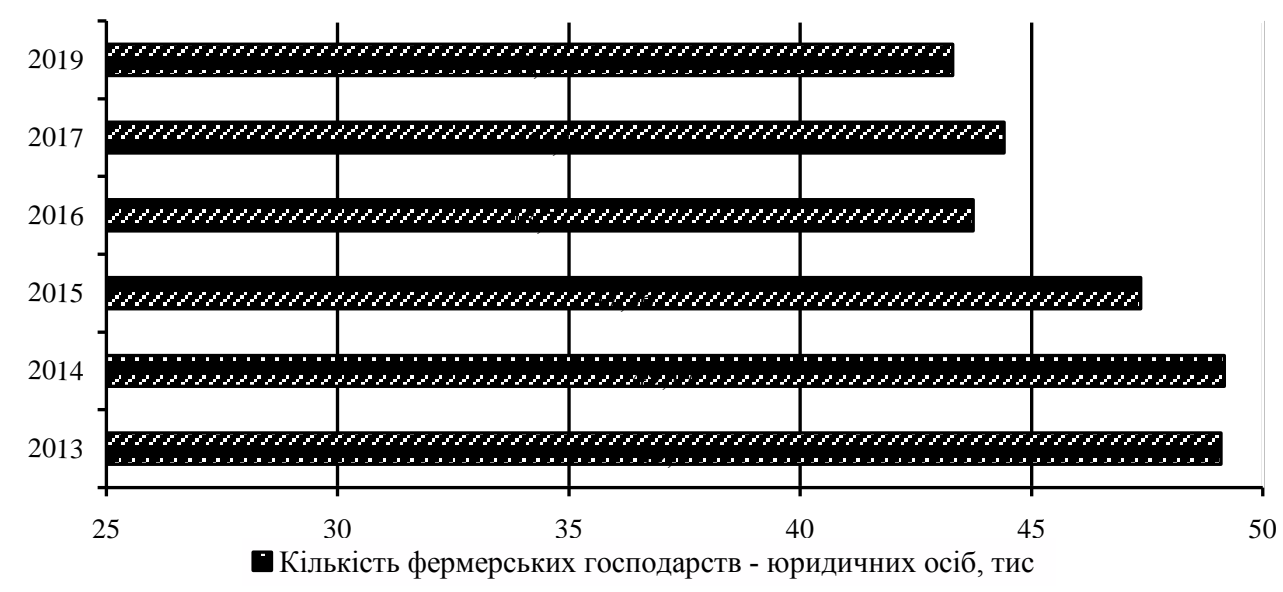

Рисунок 3 - Кількість фермерських господарств, 2013-2019 рр., тис осіб Джерело: складено за [12].

В цілому, із загального обсягу валової продукції сільського господарства України сільськогосподарські культури складають 60\%, решта $40 \%$ припадають на тваринництво i молочну продукцію. Сільськогосподарська спеціалізація визначається структурою 
фермерських господарств. Трудомісткі сільськогосподарські культури, такі як картопля, фрукти й овочі, а також молоко і м'ясо традиційно виробляються підсобними господарствами, тоді як експортно-орієнтовані зернові культури і насіння олійних культур виробляються великими корпоративними фермерськими господарствами (рис. 4-5).

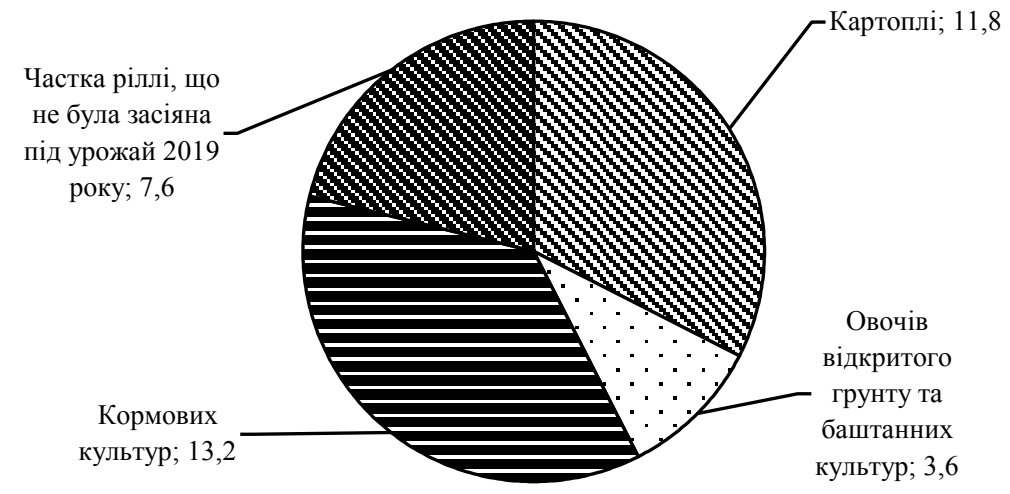

Рисунок 4 - Частка посівної площі під культурами, 2019 р. Джерело: складено за [12].

В українському виробництві сільськогосподарських культур переважає виробництво зернових, олійних культур і картоплі. Завдяки зростаючому внутрішньому попиту, нині підвищилася привабливість виробництва м'яса і молока для виробників, але, незважаючи на цей тренд, зростання були неоднозначними.

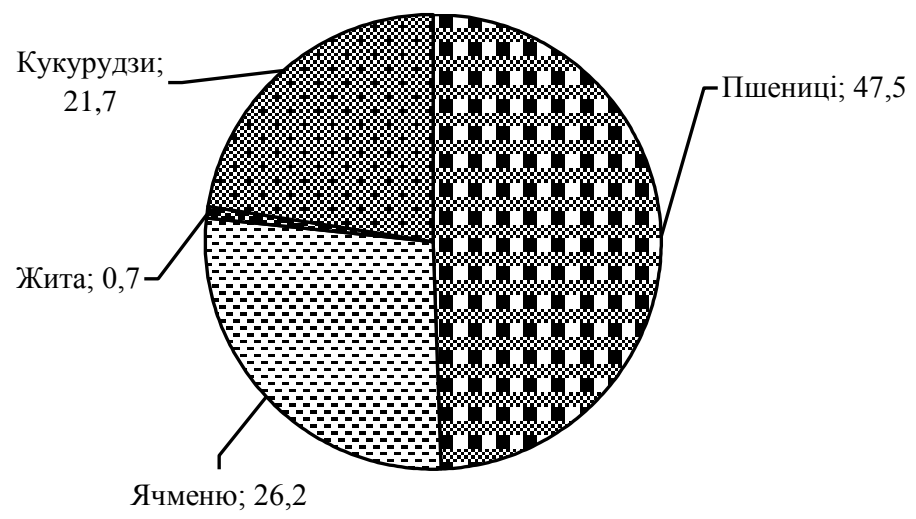

Рисунок 5 - Частка посівної площі сільськогосподарських культур у загальній посівній площі зернових та зернобобових культур, 2019 р. Джерело: складено за [12].

Україна тримала сильні позиції на ринку сільськогосподарської продукції і 100 років тому. Якщо зважати на історичні дані 1908 року, то Україна виробляла приблизно 13 млн тонн пшениці і ячменю загалом. Це 
в 2,7 рази менше, ніж у 2015 році. У той же час урожай кукурудзи того часу був значно менше - в межах 3,3 млн тонн.

В 2014-му році Україна виростила кукурудзи в 7 разів більше $-23,2$ млн тонн, ніж 100 років тому. У 2015-му році обсяги врожаю практично не змінилися в порівнянні з 2014-роком, хоча результати врожайності деяких культур зменшилися відчутно, наприклад, кукурудзи (рис. 6-7).

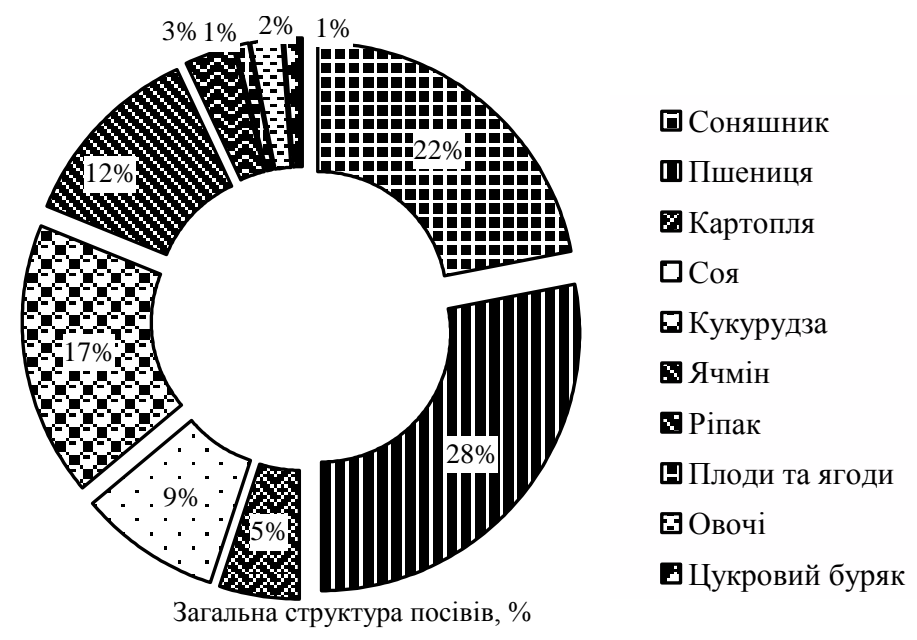

Рисунок 6 - Загальна структура посівів, 2015 р., \% Джерело: складено за [12].

Україна 100 років тому вирощувала і виробляла: 67\% зернових (пшениці - лідер у світі); 64\% тютюну; 88\% цукру (Україна виробляла більше всіх цукру в світі); 98\% антрациту; 68\% солі; 99\% коксу; 74\% сталі; $71 \%$ вугілля. Добувала 4,5\% всієї нафти в світі. До відома, якби в 1914 році Україна була б самостійною державою, доходи іiі бюджету становили б 181 млн 244 тис рублів [13].

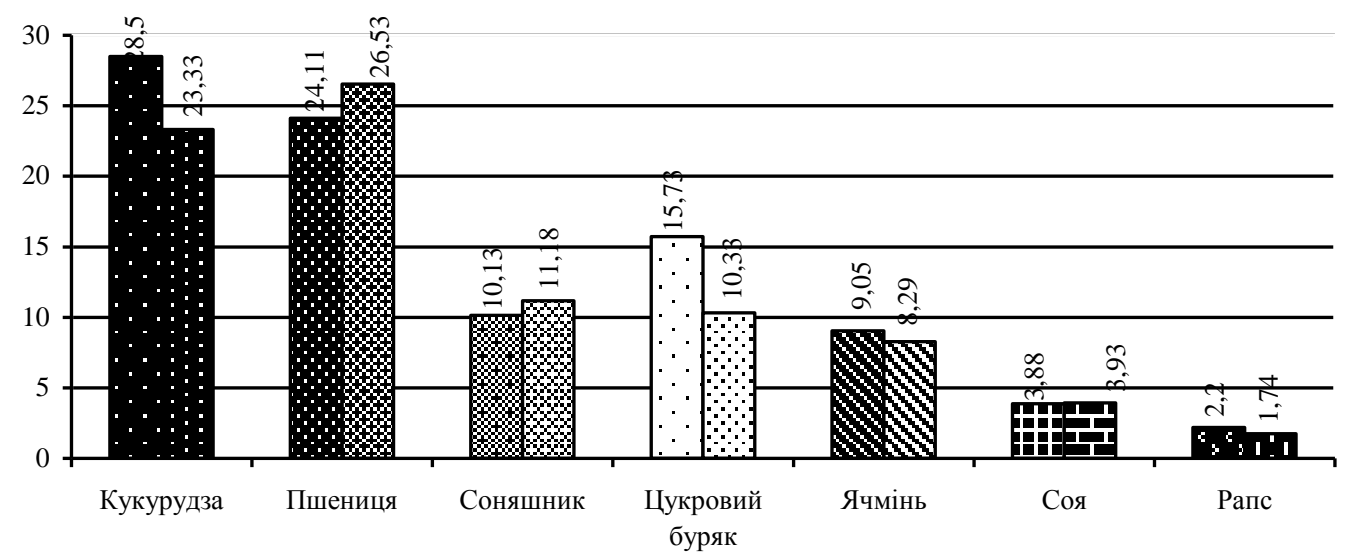

Рисунок 7 - Виробництво сільськогосподарських культур в Україні, 2014-2015 рр., млн тонн

Врожаї сільськогосподарських культур, як і раніше відстають від рівнів $\mathrm{CC}$, але поступово збільшуються, хоча і значно різняться у різних 
господарств. Близько 35\% українських фермерських господарств не можуть «вирватися» із замкнутого кола через низьку рентабельність, особливо в тваринництві (рис. 8).

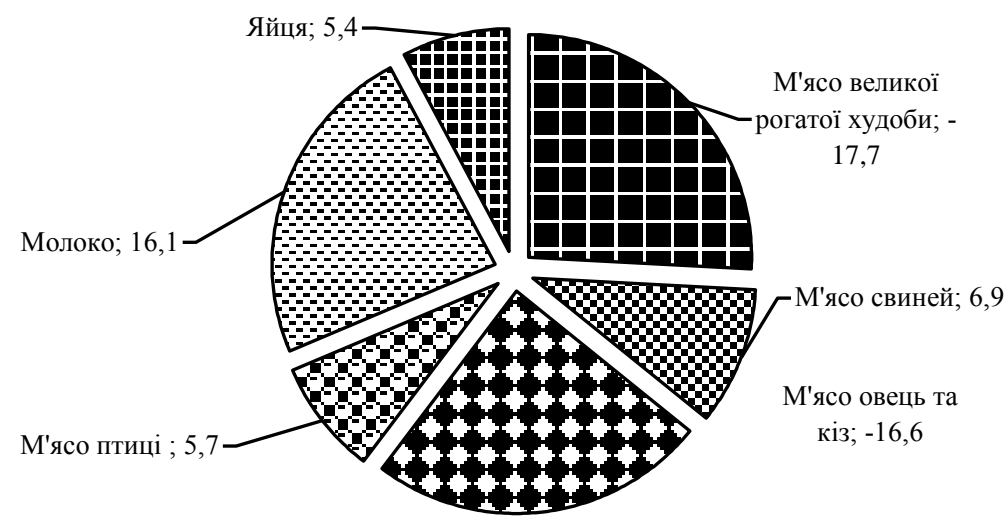

Рисунок 8 - Рентабельність виробництва продукції тваринництва, 2018 р., $\%$

Докерело: складено за [12].

М'ясний ринок є предметом занепокоєності, оскільки, незважаючи на всі спроби зупинити зниження виробництва м'яса, стиснення цього ринку триває. Споживання м'яса в розрахунку на душу населення різко скоротилося, що представляє собою серйозну проблему, з огляду на природно обумовлене значення, яке надавало споживання цього продукту в українському суспільстві в дореформений період.

Дійсно, критично низькі індикатори діяльності за останні роки викликали здивованість у суб'єктів, пов'язаних 3 питаннями агропромислового комплексу. Серед них, уряд, який розглядає високі масштаби виробництва як дещо довгоочікуване, незалежно від витрат і відноситься до самозабезпеченості як до кінцевої мети. Втім, нині основним предметом стурбованості вважаємо не обсяг виробництва: виробляється продукція всередині країни або імпортується, залежить від відносної вартості ресурсів на ії виробництво всередині країни в порівнянні 3 ввезенням 3-за кордону, а, передусім, ефективність (рентабельність) виробництва. При такому погляді на речі деяке зменшення сільгоспвиробництва цілком зрозуміло (іноді бажане) в контексті характеру аграрного господарства в Україні в дореформений період, коли його субсидування здійснювалося в значних обсягах.

Велика частка підтримки аграрної галузі здійснювалася за рахунок дешевих ресурсів для аграріїв (особливо добрив і палива), а це призводило до перевитрат і марнотратства, яке не давало пропорційного приросту обсягу виробництва. Подібні субсидії зменшилися після 1992 року; в результаті цього, а також через скорочення масштабів цінового 
регулювання, ціни на промтовари, придбані сільгоспвиробниками, зростали набагато швидше, ніж ціни на готову сільгосппродукцію.

Традиційно більшість української агропродукції - це товари рослинництва (рис. 9). Іншими словами, аграрії виробляють мало м'яса i багато зерна. Це дозволяє експортувати на міжнародний ринок зернові культури, але змушує закуповувати свинину за кордоном. До відома: курятини в Україні виробляється більше, ніж свинини. Найбільшим виробником курятини є «Миронівський хлібопродукт».

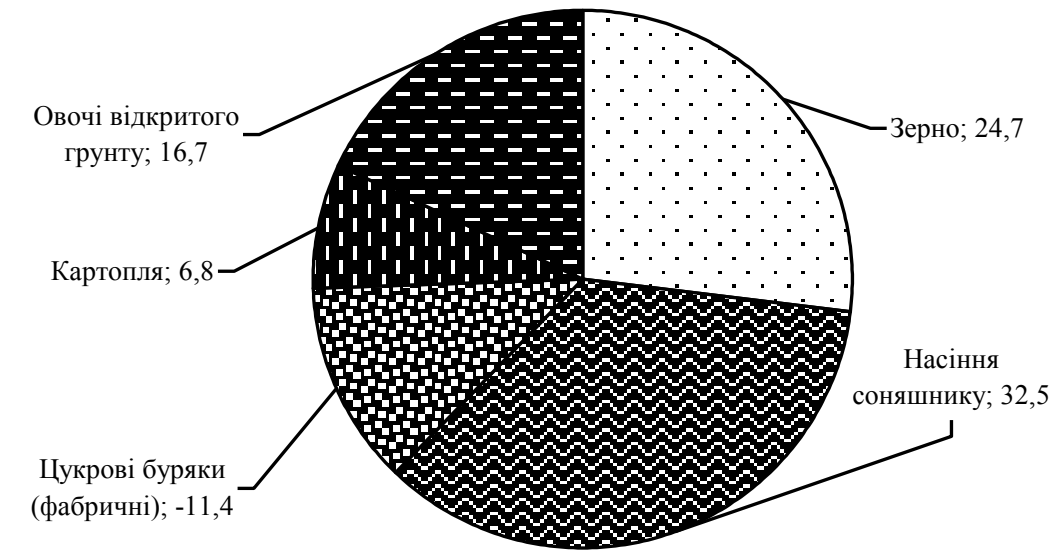

Рисунок 9 - Рентабельність виробництва продукції рослинництва, 2018 р., $\%$

Джерело: складено за [12].

Якщо розглядати кожну область України з точки зору того, чого в ній більше всього виробляють із продукції АПК, то виявиться, що по всій країні це буде молоко. На другому місці - яйця, далі - м'ясо птиці і свинина. Річ у тім, що у Вінницькій, Полтавській та Харківській - самих аграрних областях - клімат, який найкраще підходить для сільського господарства. У Вінницькій області 400 аграрних компаній.

Завдяки відносно низькому співвідношенню чисельності населення і площі орних земель, сільське господарство України має значний експортний потенціал. Воно забезпечує 18-25\% ВВП і 19\% доходів від експорту; виробництво розподіляється приблизно рівномірно між приватними фермерами (52,7\%) i корпоративними i державними господарствами (47,3\%). Крім того, Україна розташовується поблизу основних країн-імпортерів продуктів харчування і кормів: $\mathcal{C}$, Північної Африки, Близького Сходу та Азії. Товарообіг з країнами СС становить 41,5\% від загального торговельного обороту України. У першому кварталі 2019 року в порівнянні з аналогічним періодом 2018 року товарообіг 3 країнами СС зріс на 6\% - до 11,149 млрд дол США.

Україна займає 12-е місце в світі з експорту пшениці. Так, станом на 23 грудня з початку 2019/2020 року з України експортовано 29350 тис тонн зернових культур, що на 7,6 млн тонн більше ніж за аналогічний 
період минулого року. Зокрема, на зовнішні ринки поставлено: пшениці 14,5 млн тонн; ячменю - 3,7 млн тонн; жита - 5 тис тонн; кукурудзи - 10,9 млн тонн. По-суті, експортовано борошна пшеничного та інших культур 182,4 тис тонн, що на 64,3 тис тонн більше ніж за відповідний період минулого року [13].

3 приводу врожаю та експорту соняшнику, то Україна вирощує 11,2 млн тонн соняшнику, а це майже третина всього насіння, виробленого у світі. Ще одне перше місце $з$ експорту соняшникової олії - 3,3 млн тонн на рік. Інші позиції на міжнародному ринку продовольства: 2-е місце 3 експорту зернових і горіхів, 3-е - по виробництву і експорту ячменю, а також з експорту ріпаку. І сьома позиція по експорту борошна [13].

Незважаючи на наявність чорнозему і досить сприятливий клімат, в Україні низька врожайність: на одному гектарі аграрії вирощують менше кукурудзи і пшениці, ніж в країнах ЄC (рис. 10). Причини такі: нерозвинені технології; відсутність державної підтримки; невирішене питання з ринком землі. Значне виробництво зернових відбувається не за рахунок високої врожайності, а за рахунок найбільших площ.

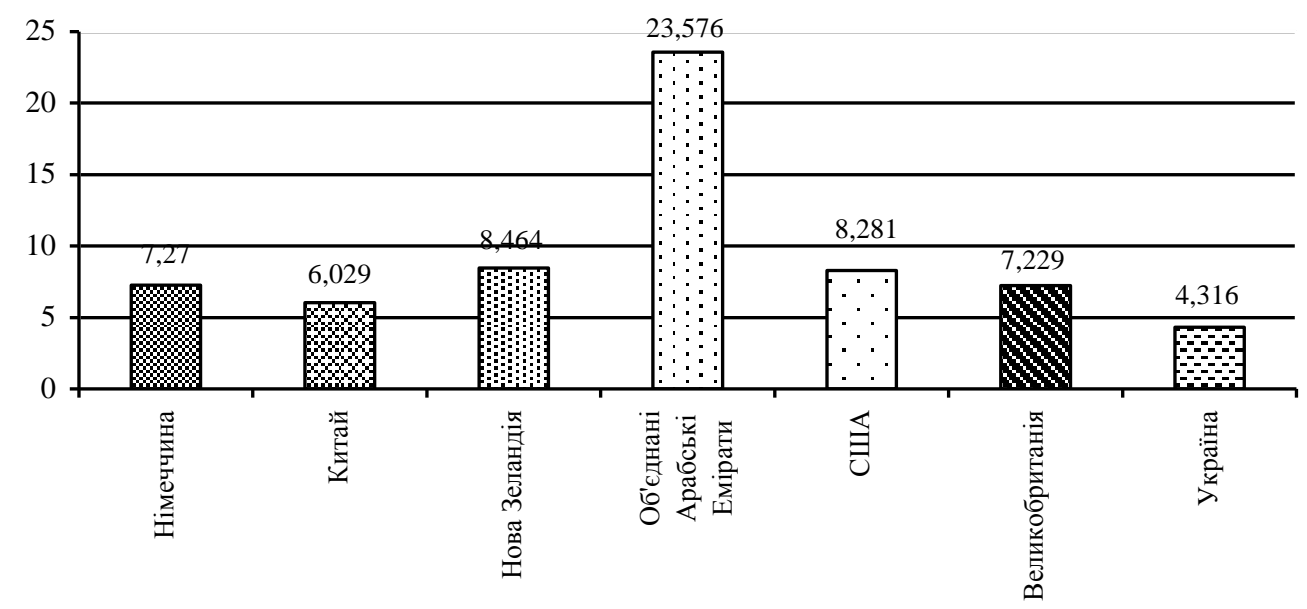

Рисунок 10 - Урожай зернових в Україні і в країнах світу, 2017 р. (кг/га) Джерело: складено за [14].

Для порівняння: у Франції і Німеччині, чия площа родючих земель подібна до України, сільськогосподарської продукції виробляється в кілька разів більше. Причина успіху сільськогосподарського комплексу ЄС - велика державна підтримка європейських фермерів і більш висока вартість продукції. Причина відставання нашої країни - неефективність АПК, бо за розмірами території, Україна є другою країною в Свропі.

Успішність будь-якого бізнесу визначається не тільки наявністю доходу, але і рівнем його максимізації. В умовах ринкової економіки завжди необхідно впроваджувати конкурентні можливості, за допомогою яких можна створювати додаткову вартість (рис. 11). 


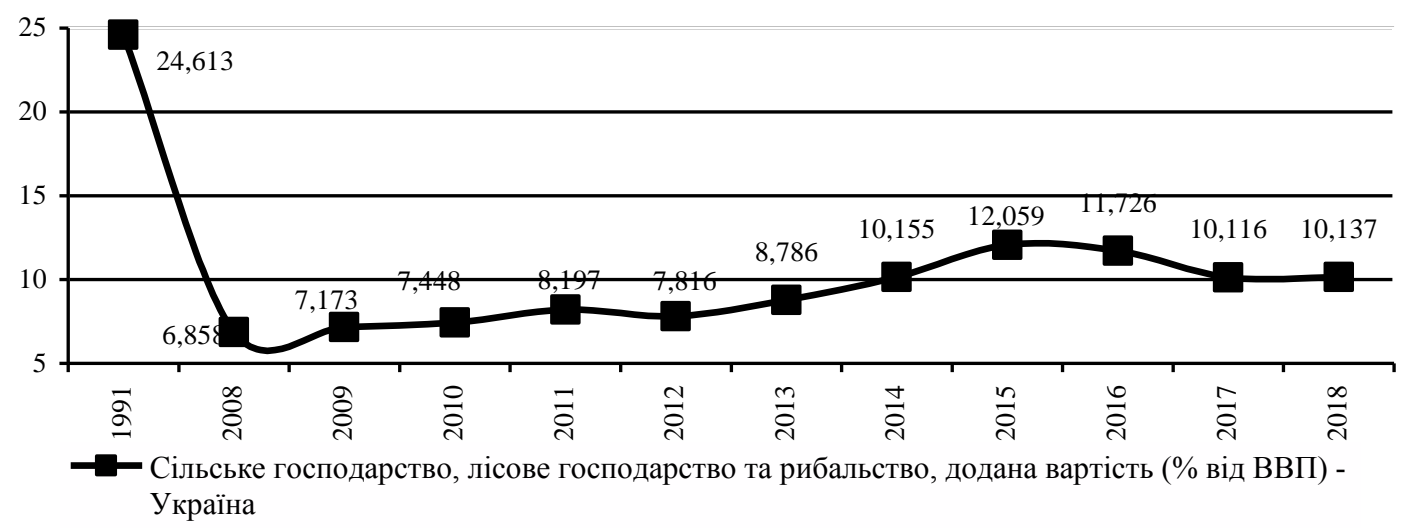

Рисунок 11 - Сільське господарство, лісове господарство та рибальство, додана вартість (\% від ВВП) - Україна, 1991-2018 рр. Джерело: складено за [14].

Як видно з таблиці обсяг експортованого масла менше, ніж зернових, а доходи, отримані за менший обсяг, можна порівняти або навіть більше. У 2015 році таке сталося вперше, раніше лідирувала пшениця. Цей тренд відображає вигоди експорту переробленої продукції (олії замість насіння) порівняно з експортом сировини (зерно кукурудзи або пшениці). Отже, важливо і надалі підтримувати сферу переробки.

Таблиця - Співвідношення виробництва і доходів від експорту, 2015 р., мЛН ТОНН

\begin{tabular}{|c|c|c|}
\hline Виробництво, млн тонн & Експорт, млн тонн & Дохід, млрд дол США \\
\hline \multicolumn{3}{|c|}{ Пшениця } \\
\hline 26,5 & 13,5 & 2,2 \\
\hline \multicolumn{3}{|c|}{ Кукурудза } \\
\hline \multicolumn{3}{|c|}{ Ячмінь } \\
\hline 8,3 & 4,6 & 3 \\
\hline \multicolumn{3}{|c|}{ Соняшникове масло } \\
\hline 4,7 & 4,0 \\
\hline
\end{tabular}

Джерело: складено за [12].

Таким чином, завдання підвищення конкурентоспроможності АПК України полягає в створенні належних умов для підвищення загального рівня рентабельності сільгоспвиробників. Міжнародний досвід свідчить, що підвищення рентабельності пов'язане із забезпеченням достатньої гнучкості, що дозволяє коригувати структуру посівів і технології у відповідь на зміни ринкових умов. Переробна промисловість, системи постачання ресурсів (у тому числі i фінансових ресурсів) сільгосппідприємствам і системи збуту продукції на українському i міжнародних ринках повинні бути достатньо гнучкими, щоб реагувати на ринкові зміни. Базою для трансформацій повинна бути програма реформ 
та інвестицій, яка допоможе усунути перешкоди, що заважають перетворенням, і сприятиме виконанню завдань розвитку інфраструктури, транспорту, зв'язку, підготовки кадрів і створення гнучких ринків факторів виробництва (землі, фінансів і праці).

Висновки. Запропоновано концептуальний підхід розвитку АПК України, що базується на таких принципах: 1) до сільських і міських суб'єктів АПК пред'являються однакові вимоги торгового, валютного i податкового режимів; 2) мотивацією для розвитку приватних сільгоспвиробників $є$ мінімальні цінові перекоси на ринках ресурсів i виробленої продукції, розвиток внутрішнього і міжнародного ринку збуту сільськогосподарської та агропромислової продукції; 3) великі агропромислові компанії не отримують привілеїв i не повинні послаблювати конкуренцію на ринках виробленої продукції, ресурсів, землі чи кредитних ресурсів; 4) результатами економічного зростання на селі користується все сільське суспільство, а його рушійними силами є: приватне комерційне конкурентоспроможне сільськогосподарське виробництво й агробізнес; 5) приватні великі і сімейні фермерські господарства та несільськогосподарські підприємства забезпечують зайнятість 3 достойною оплатою праці для чоловіків і жінок; 6) сільське населення отримує доступ до ефективно функціонуючих ринків продукції, фінансових, інформаційних та матеріально-технічних ресурсів; 7) нормативно-правова база, державні інвестиції і виробничі і соціальні послуги забезпечуються і фінансуються у децентралізований спосіб за участю всіх зацікавлених сторін.

Найкращим варіантом втілення реформ підтримки сільського господарства $\epsilon$ така система, коли всі субсидії сільгоспвиробникам розподіляються за допомогою «нейтрального» механізму, який не створює ні негативних, ні позитивних стимулів для виробництва (наприклад, виплати з розрахунку на один гектар) i, який не залежить ні від споживання сільським господарством промислових товарів і послуг, ні від виробництва сільськогосподарської продукції.

Субсидії на ресурси, придбані сільським господарством, або кредитні субсидії доцільно розподіляти не через монопольні або державні структури, а по приватних каналах на конкурсній основі (наприклад, субсидування ставки відсотка може здійснювати жодна приватна кредитна установа, що пройшла кваліфікаційний відбір, а сільгоспвиробники можуть віддавати свої ваучери на придбані в лізинг промислові товари будь-якому постачальнику, якого вони самі виберуть). Крім того, ці субсидії повинні бути доступні не тільки великим сільськогосподарським підприємствам, а всім господарствам. 


\section{Література:}

1. Bojnec, S., Latruffe, L. (2013). Farm Size, Agricultural Subsidies and Farm Performance in Slovenia. In: Land Use Policy. Vol. 32, pp. 207-217. DOI: 10.1016/j.landusepol.2012.09.016.

2. Capkovicova, A., Hlavsa, T. (2015). Approaching the Service-Based Economy: Regional Differentiated Employment Growth in Czechia. In: Studies in Agricultural Economics. Vol. 117, No. 1.pp. 1-10. DOI: 10.22004/ag.econ.206110.

3. Gorton, M., Davidova, S. (2004). Farm Productivity and Efficiency in CEE Applicants' Countries: a Synthesis of Results. In: Agricultural Economics. Vol. 30, No. 1, pp. 1-16. DOI: 10.1016/j.agecon.2002.09.002.

4. Galuzzo, N. (2015). Technical and Economic Efficiency Analysis on Italian Smallholder Family Farms Using Farm Accountancy Data Network Dataset. In: Studies in Agricultural Economics. Vol. 117, No. 1, pp. 35-42. DOI: 10.7896/j.1501.

5. Jodkiene, V., Savickiene, J., Slavickiene, A. (2013). The Economic Viability of the Farmer's Farms: Case of the New EU Countries. In: Asian Conference on the Social Sciences (ACSS 2013), PT 1 Book Series: Advances in Social and Behavioral Sciences. Vol. 3, pp. 102-108. https://hdl.handle.net/20.500.12259/86712.

6. Lerman, Z., Sutton, W.R. (2008). Productivity and Efficiency of Small and Large Farms in Transition: Evidence from Moldova. In: Post-Soviet Affairs. Vol. 24, No. 2, pp. 1-24. DOI: 10.2747/1060-586X.24.2.XX.

7. Rezitis, A.N., Tsiboukas, K., Tsoukalas, S. (2002). Measuring Technical Efficiency in the Greek Agricultural Sector. In: Applied Economics. Vol. 34, No. 11, pp. 1345-1357. DOI: 10.1080/00036840110099261.

8. Veveris, A. (2008). Improvement Possibilities of Economic Information for Analysis of the Agricultural Sector. In: Economic Science for Rural Development: Rural and Regional Development. Book Series: Economic Science for Rural Development. Vol. 15, pp. 273 279.

9. Střeleček, F. Kopta, D., Lososová J., Zdeněk R. (2012). Economic Results of Agricultural Enterprises in 2010. In: Acta Universitatis Agriculturae et Silviculturae Mendelianae Brunensis, Vol. 60, No. 7, pp. 315-328. DOI: 10.11118/actaun201260070315.

10. Střeleček, F., Lososová, J., Zdeněk, R. (2011). Economic Results of Agricultural Enterprises in 2009. Agricultural Economics. - Czech, Vol. 57, pp. 103-117. https://doi.org/10.17221/175/2010-AGRICECON.

11. Vasiliev, N. Astover, Mõtte, M. (2008). Efficiency of Estonian Grain Farms in 20002004. In: Agricultural and Food Science. Vol. 17, No. 1, pp. 31-40. DOI: https://doi.org/10.2137/145960608784182272.

12. Сільське, лісове та рибне господарство. Державна служба статистики Украӥни. 2019. URL: http://www.ukrstat.gov.ua/ (дата звернення: 15.11.19).

13. Агробизнес Украины 2017. URL: https://businessviews.com.ua/ru/economy/id/20grafikov-i-kart-kotorye-dostupno-objasnjajut-agrobiznes-ukrainy-328/ (дата звернення: 25.12.19).

14. Agriculture \& Rural Development. 2019. The World Bank Group. URL: https://data.worldbank.org/indicator (дата звернення: 15.12.19). 